\title{
Interactive Multimedia Development in Exposition Text Learning According to Learning Media Expert in Dwitunggal Junior High School, Tanjung Morawa
}

\author{
Rizki Fadila Nasution ${ }^{1}$, Khairil Ansari², Marice $^{2}$ \\ ${ }^{1}$ Master Student in State University of Medan (Unimed), Medan, Indonesia \\ ${ }^{2}$ Lecturer in State University of Medan (Unimed), Medan, Indonesia \\ rizkifadila231@gmail.com
}

\begin{abstract}
This study is aimed to develop products in the form of interactive learning multimedia in exposition teaching learning. Product development is designed using Adobe Flash CS5 Professional software. The object of this study is VII grade students of Dwitunggal Junior High School in Tanjung Morawa. The steps of developing Adobe Flash CS5 Professional multimedia for learning skills of writing the exposition text of VIII grade students of Junior High School as follows: (1) Decide, (2) Design (product design), (3) Product development, (4) Evaluate (Product test). The analysis needs to be carried out in two stages, there are: (1) literature study and (2) observation in Dwitunggal Junior High School in Tanjung Morawa. To obtain the validity of the data, it is required validation of the expert media and material. After validation is done by the two media professionals, material, and practical testing were conducted on a limited basis in 35 students of VIII grade Dwitunggal Junior High School in Tanjung Morawa. Based on the results of validations and trials on interactive multimedia products, it can be reported as follows: (1) validation of the material shows the percentage of eligibility is $86,3 \%$ with very good category (2) media validation shows the percentage of eligibility is $86.5 \%$ with very good category (4) teachers' validity (practitioner) shows the percentage of eligibility is 90, $5 \%$ with very good category. The acquisition of individual trial results is stated as "very good" with an average percentage of 83.7\%. The acquisition of small group trial results is stated as "very good" with an average percentage of $85.5 \%$ and the acquisition of limited field trial results is stated as "very good" with an average percentage of $87.3 \%$. The effectiveness of interactive multimedia products in learning of writing the exposition text seen from student learning outcomes in writing exposition text after using learning media that have been developed are in "very good" category with an average value of 88.17 and the average value before using text learning media exposition of 67.88 which is in the category of "sufficient". This proves that student learning outcomes are higher after using interactive multimedia in learning of writing exposition text with a value difference of 20.29 .
\end{abstract}

Keywords: Development; interactive multimedia; text exposition.

\section{Introduction}

Based on the results of observations and interviews which is conducted by Indonesian language teachers in the Dwitunggal Junior High School in Tanjung Morawa, there are various problems that affect the low ability of the students of Class VIII of junior high school in Learning of writing exposition texts. The most dominant problems affecting the ability of students in activities to write exposition text, include (1) the lack of student ability in pouring ideas, ideas, thoughts, and feelings into writing forms, (2) differences in background backgrounds of students so that it affects the results of each student's writing, (3) the lack of student learning that can help students in the process of writing learning text exposition, and (4) the lack of interactive learning multimedia which is packaged in the form of a $\mathrm{CD}$ (Compact Disk) that can be used in the process of learning to write text exposition teaching Indonesian language. 
In 2013 Curriculum on Indonesian Language, one of the competencies that must be achieved by VIII Grade students of junior high school is writing exposition text. Learning of writing expository texts can be found in KD 4.6 Presenting ideas and opinions in the form of text exposition of popular scientific articles (environment, social conditions, and / or cultural diversity, etc.) verbally and in writing by paying attention to the structure, linguistic aspects, and oral aspects. But in practice, students still have difficulty in writing exposition texts

To help overcome problems in Learning of writing exposition text, it requires a proper learning medium. Learning media is a tool that can be used to convey learning messages (Sanaky, 2013: 3).

Arsyad (2014: 9), explains that good media are media that are able to involve a lot of student senses because the more sensory devices involved, the greater the possibility of students to understand and understand the learning material.

The increasingly rapid development of science and technology, of course, also affect the development of instructional media. Currently, media which are considered practical in the learning process are media which is able to unite several media components (text, graphics, images, video, animation, and audio) into one. Interactive media is a computer-based media that is able to unite several components of the media into one. The computer-based learning process has indeed begun to be a solution in dealing with the problems that often arise in every learning process. Multimedia-based interactive computer-based learning that refers to the 2013 Curriculum is still minimal. This is because the 2013 curriculum was implemented for six years. In addition, the text of the exposition taught in Curriculum 2013 is complex. Based on the needs analysis, the main goal in the teaching of exposition texts is that students are able to compose / write exposition texts well. In order for learning to be more practical and directed according to basic competencies and competencies, the development of multimedia learning in exposition text writing is very necessary.

Based on the description above, it is necessary to develop an interactive learning multimedia to produce a media that can helping the learning process become more focused and able to help students to produce a composition of exposition that is intact and interesting. Multimedia interactive learning products developed for X grade students of vocational high school which have the following specifications.

1). Learning media products are multimedia interactive learning.

2). Multimedia interactive learning can be used as an individual learning media or in groups which are integrated with interactive writing learning steps, which are developed texts, which are exposition texts that directly address the basic competency guidelines, that is exposition text themed in the environment and social conditions. Interactive multimedia on exposition text learning presents related menus, there are on the menu a). The purpose of learning, KI and KD as well as learning objectives. On the menu b). The material, on this menu contains exposition definition, exposition text structure, linguistic rules and steps to write exposition text. On the menu c) Evaluation/Writing Evaluation contains multiple choice questions to test the competence of students' knowledge then a matter of description aimed at students writing good exposition text according to a predetermined theme. d) The profile contains the identity of the learning media developer and supervisor. Software used in the development of interactive multimedia, including: Microsoft Word for the formulation of material, Auto Play Media Studio Ver. 8.5.0.0 as the main program for designing learning media, Ispiring Ver. 8 and Wonder share Quiz Creator to create an interactive Adobe Photoshop CS6 questionnaire for creating image display designs, buttons, and CD covers. 


\section{Review of Literature}

\subsection{The Concept of Interactive Multimedia Development}

According to Setyosari (2015: 277) development is a process used to develop and validate educational products. Development can be in the form of processes, products, and designs. The purpose of development is to produce a product based on the findings of a series of trials then carried out revisions and so on to obtain adequate or feasible results or products.

In line with Setyosari According to Gay (in Sitanggang 2016: 15) Development Research is an attempt to develop an effective product for school use, and not to test theory. Whereas Borg and Gall (1983: 772) define development research as a process used to develop and validate educational products. The steps of this process are usually referred to as the R\&D cycle, which is tailored to the development used.

So it can be concluded that research development is a method for developing a pattern of a study both in terms of processes and products or the results of the development that has been done, the results of products that have been developed can be in the form of training materials for teachers, learning materials, media, questions, and management systems in learning.

\subsection{Adobe Flash CS5 Professional}

Adobe Flash is a program specifically designed by Adobe and a standard application program for professional authoring tools used to create animations and bitmaps that are very attractive for the purposes of building interactive and dynamic websites.

According to Palelupu (2014: 11) Adobe Flash CS5 is an animation program that has been widely used by animators to produce professional animation. Learning media made from the program are more often found for subject matter that is dominated by images.

According to Emut (in Yunita 2017: 4) this vector-based animation software can be used to produce web animations, presentations, games, films and interactive learning CDs. This media also combines and synergizes all media consisting of text, graphics, photos, videos, animations, music, narration and interactivity that can be programmed based on learning theory. In general, the benefits that can be obtained from multimedia are the learning processes that are more interesting, more interactive, the amount of teaching time can be reduced, the quality of student learning can be improved and the teaching and learning process can be done anywhere and anytime, and student learning attitudes can be improved.

Based on some opinions it was concluded that Adobe Flash CS5 is a professional application program for drawing graphics and vector animations or bitmap images. Adobe Flash uses a programming language called Action Script that first appeared in Flash CS5. Adobe Flash CS5 is a Windows-based program, therefore users can use this program more easily because it can design visually.

\subsection{Writing the Exposition Text}

Exposition is a translation of the word exposition derived from English. This word means a detailed explanation. Based on the basic words, the nature of the exposition is a text that provides a detailed description of an information. Priyatni (2014: 91) states that the exposition text is the text used to convince readers of opinions expressed with a number of supporting arguments. 
Nurudin (in Octavia 2015: 27), writing an exposition text is a whole series of activities in order to express ideas and convey them through written language to others so that they are easily understood.

According to Hyland (2003: 3) said that writing is seen as a product constructed from the writer's command of grammatical and lexical knowledge, and writing development is considered to be the result of imitating and manipulating models provided by the teacher. Writing is not only arranging words into sentences but it is also arranging sentences or paragraphs. Then, it is neither an easy nor spontaneous activity. In writing, students do not only have to keep the idea in mind and then write it, they need to have creativity to express and develop their idea as well.

That writing is seen as a product that is built from the lexical and grammatical knowledge of the writer, the development of writing is considered as the result of imitating and manipulating the models given by the teacher. Writing not only arranges words into sentences but also organizes sentences or paragraphs. This is not an easy and non-spontaneous activity. In writing, students not only think of the idea and then write it, they also need creativity to express and develop their ideas as well.

Meanwhile Rahayu (2007: 160) states "Exposition or exposure is a form of writing that seeks to explain and describe a subject that can broaden the view or knowledge of the reader."

\section{Research Method}

This research was conducted at Dwitunggal Junior High School, Jl. Medan-Tanjung Morawa Km. 14.5 Deli Serdang, North Sumatra in VIII grade students. The research subjects were students of VIII- 1 class with a total number of 35 students, and the object of the study was interactive multimedia in learning of exposition texts.

\section{Discussion}

This study is a research development that is the development of interactive media on exposition text learning for VIII grade students of Junior High School in Tanjung Morawa. This research resulted in a product in the form of exposition text learning media using adobe flash CS5 professional that has been adapted to the needs of students and teachers.

Development of interactive multimedia in exposition text learning using research and development $(\mathrm{R} \& \mathrm{D})$ methods. The development model in this study follows the flow of DDDE (Decide, Design, Develop, and Evaluate), Tegeh, et al (2014: 16). The process of implementing the interactive multimedia development consists of 4 stages, there are: (1) the stage of decide, (2) the stage of design, (3) the stage of develop, and (4) the stage of evaluation. A description of the stages of the DDD-E development model to produce a final product of research in the form of interactive multimedia exposition text learning will be presented in the sections below.

\section{a. Stage I: Decide}

Decide or set goals and program material, at this stage it has 4 stages, there are: (1) Setting learning objectives; at this stage, the authors plan the stages of interactive multimedia products. The first stage is determining instructional objectives that is activities to determine core competency and standards competency to be used. Besides determining the indicators and 
achievement of learning objectives to be achieved later; (2) Determining the theme or scope of multimedia. The second stage is determining the theme or scope to be developed in an interactive multimedia product. Determine the material and also pay attention to the language that will be used in learning, (3) Develop the prerequisite abilities, at this third stage determine the knowledge and ability of students to receive lessons to be given; (4) Assessing resources, activities in the fourth stage, namely evaluating the availability of computers and natural resources available in the scope of the school. This writer must see the infrastructure provided in the scope of the school that will be a place of research.

\section{b. Stage II: Design}

After determining the contents of interactive multimedia, then at this design stage determine the stages of the sequence of media to be developed. At the design stage, the researcher must determine the outline of the material to be developed in interactive multimedia, then determine the characteristics of the targets that will affect the presentation or appearance of the media. Next, determine the type of menu structure in the multimedia to be processed. Then, in the design stage, the writer must pay attention to how to use the navigation buttons on the display when presenting interactive multimedia in order to make it easier to operate interactive multimedia in the learning process.

\section{c. Stage III: Develop}

At the develop stage or developing activities to produce media elements and create multimedia displays, this development stage is the final stage of the process of making interactive multimedia displays, because at this stage a component of the media will be used in making interactive multimedia, such as matching an animation with material, video or audio as a support. In this stage, the determinant of the developed multimedia results can be said to be interactive or not in a learning process.

\section{d. Stage IV: Evaluate}

Evaluate is checking the entire design and development process, at this stage an assessment is carried out at each stage of development and not just the final product. In the decide stage an assessment of the accuracy of the topic with multimedia and the feasibility of initial research results to match the multimedia product as a solution to overcome the learning problem. In the design phase, an outline sequence is performed to run the interactive multimedia. Furthermore, in this stage, an assessment of the components of interactive multimedia elements, namely images, animation, video and audio. After this stage has been given an assessment, then interactive multimedia is feasible to be displayed and used in the learning process.

As for some of the results of the display development of learning media exposition text based interactive multimedia are as follows.

\section{Front page of Interactive Multimedia in Exposition Text Learning.}

The front page has 1 navigation button to enter into the interactive multimedia of exposition text learning. 


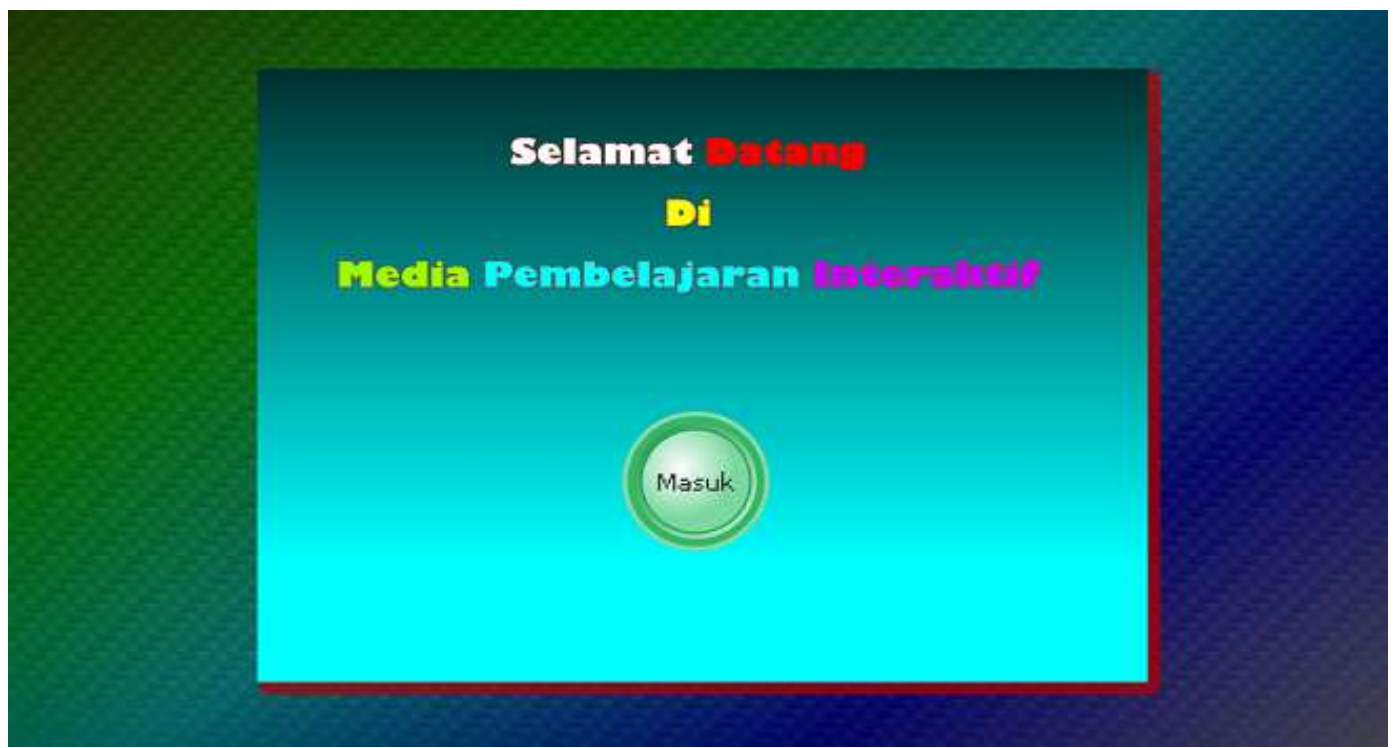

Figure 1. Front page of Interactive Multimedia in Exposition Text Learning

2. Menu / Home Display Results

Menu / home display is a display that contains the entire contents of learning media, starting from $\mathrm{KI}$ and $\mathrm{KD}$, indicators, and learning objectives, materials, quizzes, instructions, profiles.

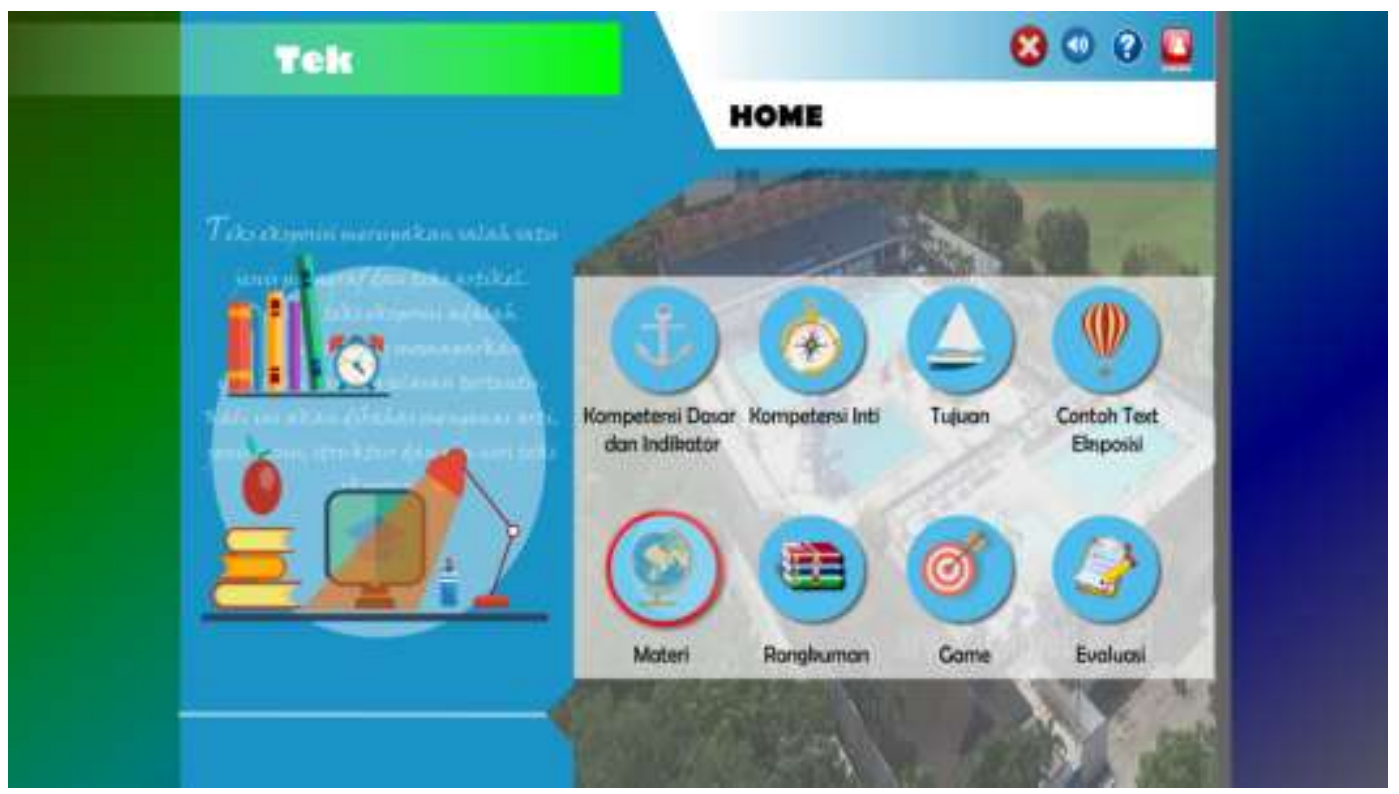

Figure 2. Menu / Home Display

Table 1. Description of Media Expert Learning Assessment Results

\begin{tabular}{|c|c|c|c|c|c|c|c|c|}
\hline \multirow{2}{*}{ No } & \multirow{2}{*}{ Aspect } & \multirow{2}{*}{\multicolumn{2}{|c|}{ Indicator }} & \multicolumn{2}{|c|}{ Expert } & \multirow[t]{2}{*}{ Total } & \multirow{2}{*}{$\%$} & \multirow{2}{*}{ Criteria } \\
\hline & & & & 1 & 2 & & & \\
\hline 1 & & 1 & $\begin{array}{l}\text { Description of } \\
\text { multimedia products }\end{array}$ & 5 & 5 & 10 & 100 & $\begin{array}{l}\text { Very } \\
\text { Good }\end{array}$ \\
\hline
\end{tabular}




\begin{tabular}{|c|c|c|c|c|c|c|c|c|}
\hline & \multirow{2}{*}{$\begin{array}{l}\text { Guide and } \\
\text { Informa- } \\
\text { tion }\end{array}$} & 2 & $\begin{array}{l}\text { Guide to using } \\
\text { multimedia software }\end{array}$ & 5 & 5 & 10 & 100 & $\begin{array}{l}\text { Very } \\
\text { Good }\end{array}$ \\
\hline & & 3 & Assistance facilities & 5 & 4 & 9 & 90 & $\begin{array}{l}\text { Very } \\
\text { Good }\end{array}$ \\
\hline & & & Total & & & 29 & 96,6 & $\begin{array}{l}\text { Very } \\
\text { Good }\end{array}$ \\
\hline \multirow[t]{10}{*}{2} & \multirow[t]{10}{*}{$\begin{array}{c}\text { Software } \\
\text { Operations }\end{array}$} & 4 & $\begin{array}{l}\text { Ease of installation or } \\
\text { configuration settings }\end{array}$ & 5 & 5 & 10 & 100 & $\begin{array}{l}\text { Very } \\
\text { Good }\end{array}$ \\
\hline & & 5 & $\begin{array}{l}\text { Appropriate use of } \\
\text { media navigation } \\
\text { symbols }\end{array}$ & 5 & 5 & 10 & 100 & $\begin{array}{l}\text { Very } \\
\text { Good }\end{array}$ \\
\hline & & 6 & $\begin{array}{l}\text { Ease of use of } \\
\text { navigation keys } \\
\text { (usability) }\end{array}$ & 5 & 5 & 10 & 100 & $\begin{array}{l}\text { Very } \\
\text { Good }\end{array}$ \\
\hline & & 7 & $\begin{array}{l}\text { Search and link } \\
\text { accuracy (hyperlink) }\end{array}$ & 4 & 4 & 8 & 80 & Good \\
\hline & & 8 & Interface quality & 5 & 5 & 10 & 100 & $\begin{array}{l}\text { Very } \\
\text { Good }\end{array}$ \\
\hline & & 9 & $\begin{array}{l}\text { Operational consistency } \\
\text { of software }\end{array}$ & 5 & 5 & 10 & 100 & $\begin{array}{l}\text { Very } \\
\text { Good }\end{array}$ \\
\hline & & 10 & $\begin{array}{l}\text { Software operational } \\
\text { reliability from errors }\end{array}$ & 4 & 5 & 9 & 90 & $\begin{array}{l}\text { Very } \\
\text { Good }\end{array}$ \\
\hline & & 11 & $\begin{array}{l}\text { Required operating } \\
\text { system support }\end{array}$ & 5 & 5 & 10 & 100 & $\begin{array}{l}\text { Very } \\
\text { Good }\end{array}$ \\
\hline & & 12 & $\begin{array}{l}\text { Support device } \\
\text { (hardware) required }\end{array}$ & 5 & 5 & 10 & 100 & $\begin{array}{l}\text { Very } \\
\text { Good }\end{array}$ \\
\hline & & 13 & $\begin{array}{l}\text { Interaction stimulus- } \\
\text { response users (users) } \\
\text { with the system }\end{array}$ & 5 & 5 & 10 & 100 & $\begin{array}{l}\text { Very } \\
\text { Good }\end{array}$ \\
\hline & & & Total & & & 97 & 97 & $\begin{array}{l}\text { Very } \\
\text { Good }\end{array}$ \\
\hline \multirow[t]{2}{*}{3} & \multirow{2}{*}{$\begin{array}{l}\text { Systematic } \\
\text { s, } \\
\text { Aesthetics }\end{array}$} & 14 & $\begin{array}{l}\text { Systematic display } \\
\text { screen (screen) media }\end{array}$ & 5 & 5 & 10 & 100 & $\begin{array}{l}\text { Very } \\
\text { Good }\end{array}$ \\
\hline & & 15 & $\begin{array}{l}\text { Menu facilities in the } \\
\text { media }\end{array}$ & 5 & 5 & 10 & 100 & $\begin{array}{l}\text { Very } \\
\text { Good }\end{array}$ \\
\hline
\end{tabular}




\begin{tabular}{|c|c|c|c|c|c|c|c|}
\hline \multirow[t]{14}{*}{$\begin{array}{l}\text { and Media } \\
\text { Principles }\end{array}$} & 16 & $\begin{array}{l}\text { Acceleration of letters, } \\
\text { numbers and symbols }\end{array}$ & 5 & 5 & 10 & 100 & $\begin{array}{l}\text { Very } \\
\text { Good }\end{array}$ \\
\hline & 17 & $\begin{array}{l}\text { Visual quality } \\
\text { (resolution) of graphics } \\
\text { or images }\end{array}$ & 5 & 5 & 10 & 100 & $\begin{array}{l}\text { Very } \\
\text { Good }\end{array}$ \\
\hline & 18 & $\begin{array}{l}\text { Color composition and } \\
\text { resolution on the screen }\end{array}$ & 5 & 5 & 10 & 100 & $\begin{array}{l}\text { Very } \\
\text { Good }\end{array}$ \\
\hline & 19 & $\begin{array}{l}\text { Matching text color } \\
\text { with background }\end{array}$ & 5 & 5 & 10 & 100 & $\begin{array}{l}\text { Very } \\
\text { Good }\end{array}$ \\
\hline & 20 & $\begin{array}{l}\text { Acceleration text, } \\
\text { visual, audio and } \\
\text { animation }\end{array}$ & 5 & 5 & 10 & 100 & $\begin{array}{l}\text { Very } \\
\text { Good }\end{array}$ \\
\hline & 21 & Narrator voice clarity & 5 & 5 & 10 & 100 & $\begin{array}{l}\text { Very } \\
\text { Good }\end{array}$ \\
\hline & 22 & $\begin{array}{l}\text { Ease of understanding } \\
\text { language in narration }\end{array}$ & 4 & 4 & 8 & 80 & Good \\
\hline & 23 & $\begin{array}{l}\text { Narration free from } \\
\text { noise }\end{array}$ & 4 & 3 & 7 & 70 & Good \\
\hline & 24 & $\begin{array}{l}\text { Narration is } \\
\text { communicative }\end{array}$ & 5 & 4 & 9 & 90 & $\begin{array}{l}\text { Very } \\
\text { Good }\end{array}$ \\
\hline & 25 & $\begin{array}{l}\text { Compatibility of back } \\
\text { sound with presentation } \\
\text { material }\end{array}$ & 4 & 3 & 7 & 70 & Good \\
\hline & 26 & $\begin{array}{l}\text { Back sound settings or } \\
\text { controls }\end{array}$ & 4 & 3 & 7 & 70 & Good \\
\hline & 27 & $\begin{array}{l}\text { Interlaced and } \\
\text { progressive scan } \\
\text { selection }\end{array}$ & 4 & 4 & 8 & 80 & Good \\
\hline & 28 & $\begin{array}{l}\text { Use of video / } \\
\text { animation resolution } \\
\text { (pixel) }\end{array}$ & 4 & 4 & 8 & 80 & Good \\
\hline & 39 & $\begin{array}{l}\text { The suitability of the } \\
\text { object / video / } \\
\text { animation with the } \\
\text { material }\end{array}$ & 4 & 4 & 8 & 80 & Good \\
\hline
\end{tabular}




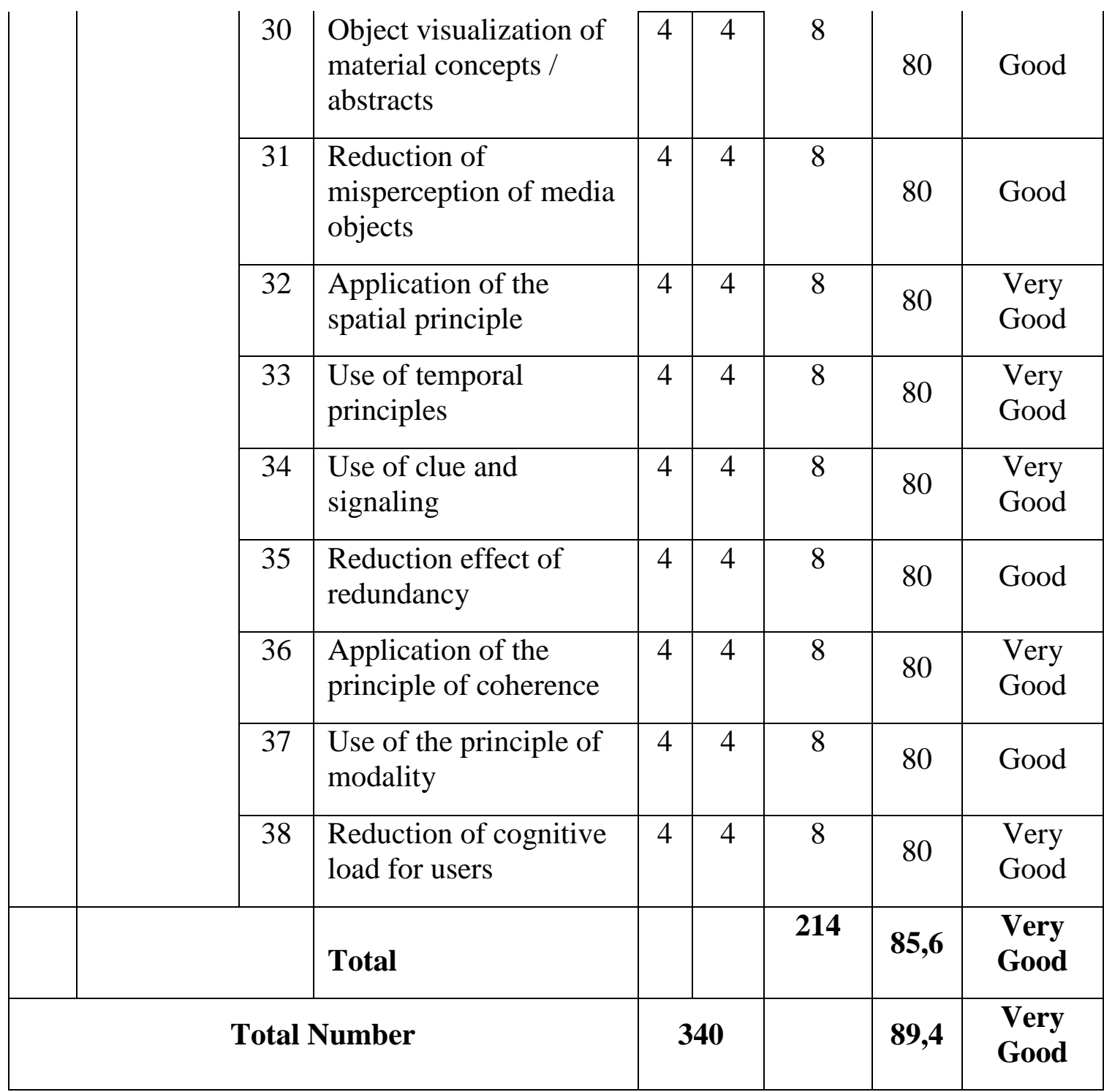

Table 2. Criteria for the percentage of indicators appearing on Interactive Multimedia on exposition text learning that has been developed

\begin{tabular}{|c|c|c|}
\hline No & Answer & Score \\
\hline A & Very Good & $81 \% \leq \mathrm{X}<100 \%$ \\
\hline B & Good & $61 \% \leq \mathrm{X}<80 \%$ \\
\hline C & Sufficient & $41 \% \leq \mathrm{X}<60 \%$ \\
\hline D & Poor & $21 \% \leq \mathrm{X}<40 \%$ \\
\hline E & Very Poor & $0 \% \leq \mathrm{X}<20 \%$ \\
\hline
\end{tabular}

(Sugiyono, 2011: 118) 
The conclusion of the results of the students' responses of VIII-1 class Dwitunggal Junior High School in Tanjung Morawa that is interactive multimedia on exposition text learning that has been developed is declared feasible and meets the needs with the criteria of "Very Good". This means that learning media developed have an increase in development and can meet the needs of learning.

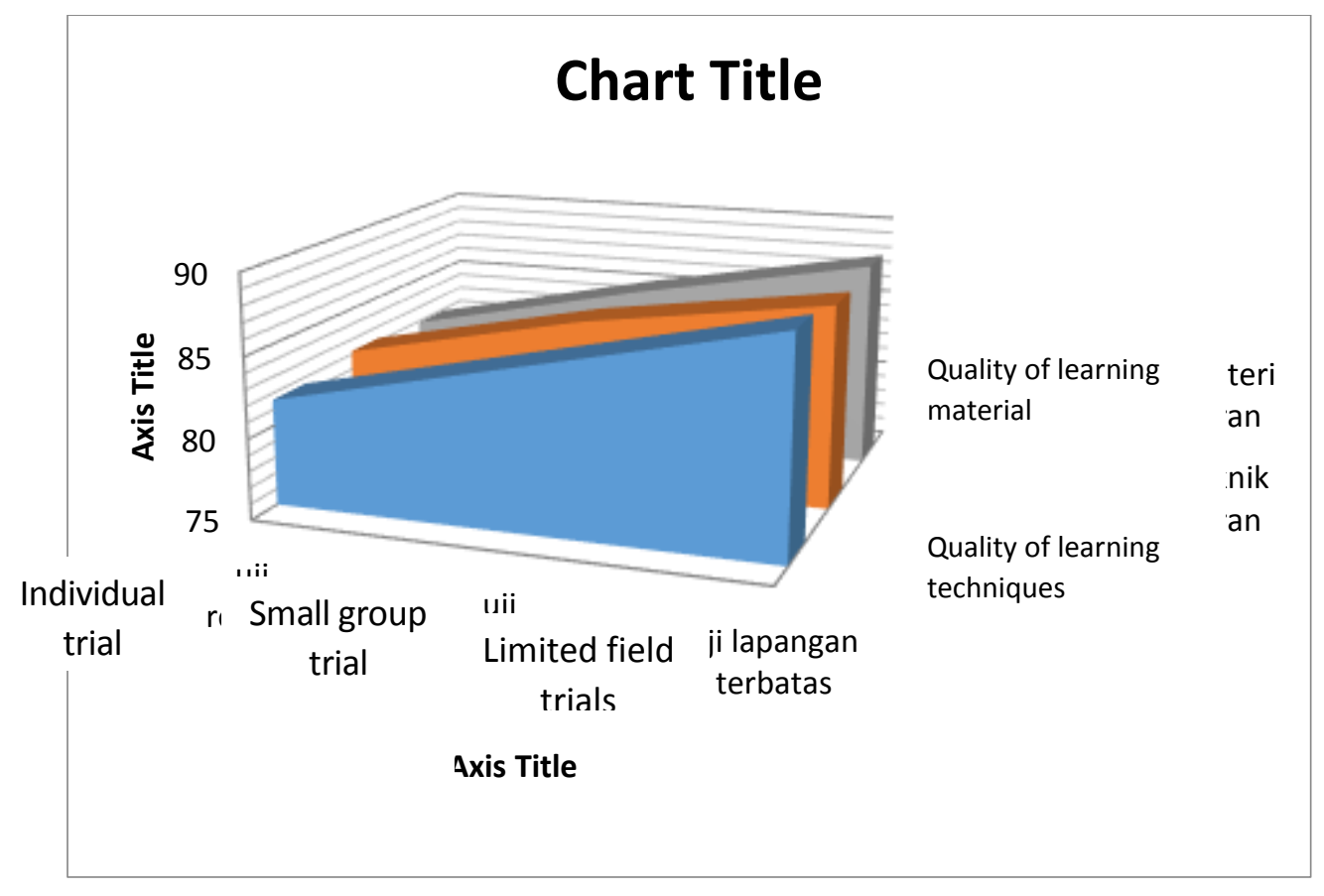

Figure 3. Diagram of Acquisition of Each Test

Table 3. Data on Learning Exposition Text

\begin{tabular}{|c|c|c|}
\hline Student Number & Pre-test & Post-test \\
\hline 1 & 68 & 87 \\
\hline 2 & 62 & 75 \\
\hline 3 & 62 & 87 \\
\hline 4 & 75 & 93 \\
\hline 5 & 75 & 93 \\
\hline 6 & 68 & 87 \\
\hline 7 & 62 & 93 \\
\hline 8 & 75 & 93 \\
\hline 9 & 68 & 93 \\
\hline 10 & 62 & 87 \\
\hline
\end{tabular}




\begin{tabular}{|c|c|c|}
\hline 11 & 75 & 93 \\
\hline 12 & 62 & 87 \\
\hline 13 & 56 & 81 \\
\hline 14 & 75 & 93 \\
\hline 15 & 75 & 93 \\
\hline 16 & 68 & 93 \\
\hline 17 & 75 & 87 \\
\hline 18 & 75 & 93 \\
\hline 19 & 62 & 87 \\
\hline 20 & 62 & 87 \\
\hline 21 & 62 & 68 \\
\hline 22 & 56 & 75 \\
\hline 23 & 75 & 93 \\
\hline 24 & 62 & 81 \\
\hline 25 & 62 & 87 \\
\hline 26 & 68 & 87 \\
\hline 27 & 68 & 93 \\
\hline 28 & 75 & 87 \\
\hline 29 & 68 & 93 \\
\hline 30 & 75 & 93 \\
\hline 31 & 68 & 93 \\
\hline 32 & 50 & 81 \\
\hline 33 & 75 & 87 \\
\hline 34 & 75 & 93 \\
\hline 35 & 75 & 93 \\
\hline Total & 2376 & 3086 \\
\hline Average & 67,88 & $\mathbf{8 8 , 1 7}$ \\
\hline
\end{tabular}

Based on the table above, it is obtained data that student learning outcomes before using the fable story text module assisted by film children obtained an average score of 67.88 with 
the category "Sufficient" meaning that the value achieved by students needs to be improved while, student learning outcomes after using the fable story text module assisted by the film children get an average score of 88.17 with the category "Very Good" meaning the student's grade is better than before.

\section{Conclusion}

Development of interactive multimedia in exposition text learning by using Adobe Flash CS5 5 software. The development process uses the stages of DDD-E (Decide, Design, Develop - Evaluate) by Tegeh, Decide means setting and planning multimedia products to be produced, Design means designing multimedia creation, Develop means developing activities that combine all multimedia components and finally evaluate which means evaluation of interactive multimedia that was developed. The resulting product is an interactive multimedia on the exposition text learning that is feasible and effective to improve the learning outcomes of eighth grade students of Dwitunggal Junior High School in Tanjung Morawa.

The feasibility of developing interactive multimedia in learning of writing exposition text is considered appropriate for use in the learning process because all assessment results are in the "very good" category. The results of the validation by the material experts stated "very good" with all aspects of the assessment got an average of $87.6 \%$, and the results of the validation by the media design experts stated "very good" with all aspects of the assessment getting an average of $89.4 \%$ stated "very good". Then the results of the response of Indonesian language teachers with an average of $90.5 \%$ on the criteria of "very good". The acquisition of individual trials results was stated as "very good" with an average percentage of $81.9 \%$. The acquisition of small group trial results was stated as "very good" with an average percentage of $85.1 \%$ and the acquisition of the limited field trials results was stated as "very good" with an average percentage of $88 \%$.

The effectiveness of interactive multimedia products in Learning of writing exposition text viewed from the results of students' learning skills in writing exposition text after using learning media that have been developed are in "very good" category with an average value of 88.17 and the average value before using learning media exposition text of 67.88 which is in "good" category. This proves that student learning outcomes are higher after using interactive multimedia in Learning of writing exposition text with a value difference of 20.29.

\section{References}

Abidin, Y. (2014). Desain Sistem Pembelajaran dalam Konteks Kurikulum 2013. Bandung: PT Refika Aditama. (2015). Pembelajaran Multiliterasi. Bandung: PT Refika Aditama.

Ann Hogue and Alice Oshima. (2007). Introduction Academic Writing. USA: Longman.

Azhar A. (2009). Media pembelajaran. Jakarta: PT Rajawali Pres.

Beach, R.W. and Marshal, J.D. (1991). Teaching literature in the secondary school. Orlando: Harcourt Brace Javanovich, Inc.

Borg, W. R. and Gall, M. D. (1983). Educational research: an introduction (4^ ${ }^{\wedge}$ th ed). New York: Longman.

Caldwell, J. S. (2008). Comprehension assessment: a classroom guide. New York: The Guilford Press.

Danandjaja, J. (2007). Foklor Indonesia: Ilmu gossip, dongeng, dan lain-lain. Jakarta: Pustaka Utama Grafiti. 
Darmawan, D. (2014). Inovasi pendidikan: pendekatan praktik teknologi multimedia dan pembelajaran online. Bandung: PT Remaja Rosdakarya.

Daryanto. (2013). Media pembelajaran. Yogyakarta: Gava Media.

Dick, W. Carey, L. and Carey, J. O. (2005). The systematic design of instruction ( $6^{\wedge}$ th ed). New York: Addison-Wesley Educational Publishers Inc.

Drabenstott, K.M. (2003). Interactive multimedia for library-user education. Portal Libraries and the Academy. Baltimore Vol. 3, Iss. 4.

Dalman. (2014). Keterampilan menulis. Jakarta: raja Grafindo Persada

Gary Woolley. (2014). Developing Literacy in the Primary Classroom. SAGE Publications Ltd. California

Gillet, J. W. and Charles T. (1986). Understanding reading problems: assessment, and instruction second edition. USA: Little, Brown and Company.

Goran, M.I. and Reynolds, K. (2005). Interactive multimedia for promoting physical activity (IMPACT). Children.Obesity Research. Vol. 13 No. 4.

Green, T. D. and Brown, A. (2002). Multimedia projects in the classroom. United States of America: Corwin Press, Inc.

Harbarth, S. (1996). The educational technology handbook; a comprehensive guide process and products for learning. New Jersey: Educational.

Harris, A. J. and Sipay, E. R. (1980). How to increase reading ability. New York: Longman.

Holub, R. C. (1984). Reception theory: a critical introduction. London and New York: Methuen.

Hassan, Mahmoud. (2015). Suggested Strategy for Developing Critical Literacy. International Journal of Humanities and Social Science. www.ijhssnet.com

Ivers, K.S \& Barron, A.E. (2010). Multimedia projects in education designing, producing, and assessing. California: Libraries Unlimited an Imprint of ABC-CLIO, LLC.

Izmirli, K. \& Kurt, A.A. (2016). Effects of modality and pace on achievement, mental Effort, and positive affect in multimedia learning environments. Journal of educational computing research. Vol. 54(3) 299-325.

Jhon, Foster. (2008). Effective Witting Skills for Public Relations. London and Philadelphia: Kogan Page

Kusmayadi, et al. (2017). Pengembangan Multimedia Cerita Rakyat.

Sebagai Penumbuhan Karakter Siswa.Jurnal Pendidikan:Teori, Penelitian, dan Pengembangan Volume: 2 Nomor: 7 Tersedia secara online http://journal.um.ac.id/index.php/jptpp/ EISSN: 2502-471X DOAJ-SHERPA/RoMEO-Google Scholar-IPI

Kusyani, Diah. (2017). Pengembangan Multimedia Interaktif untuk Pembelajaran Membaca Sastra Lama berdasarkan Teori Resepsi bagi Siswa SMP. Jurnal UNY

Lorrie, Blair. (2016). Writing a Graduate Thesis or Disertation. USA. Sense Publisher

Mayer, R. E. (2009). Multimedia learning. Yogyakarta: Pustaka Pelajar.

Mitchell, D. (2003). Children's literature, an invitation to the world. Boston: Ablongman.

Muhsin Kalida and Moh. Mursid. (2015). Gerakan Literasi Mencerdaskan Negeri. Yogyakarta: Cakruk Publishing.

Muntihanah. (2016). Cerita Ebhi Dan KhandeiSebagai Bahan Bacaan Anak. (Ebhi, Khandei Story as Reading Material for Children). Jurnal Ilmiah Metasastra, Vol. 9 No. 1, January 2019

Nurgiyantoro, Burhan. (2010). Sastra Anak: Pengantar Pemahaman Dunia Anak. Yogyakarta: Gadjah Mada University Press.

Nunung Fatimah. (2017). Pengembangan Buku Cerita Rakyat Bima Berbasis Kearifan Lokal (Sebagai Penunjang Gerakan Literasi).Jurnal Ilmiah, NOSI Vol. 5, No. 3, 17 January 2019 
Budapest International Research and Critics in Linguistics and Education (BirLE) Journal

Volume 2, No 4, November 2019, Page: 245-258

e-ISSN: 2655-1470 (Online), p-ISSN: 2655-2647 (Print)

www.bircu-journal.com/index.php/birle

emails: birle.journal@gmail.com

birle.journal.qa@gmail.com

Nurhasanah, Prita, Diah. (2016). Perbedaan Hasil Belajar Menulis Narasi Reproduksi Antara Siswa Yang Memperoleh Model Multiliterasi Transformasi Dan Model Moody (Penelitian Kuasi Eksperimen Pada Siswa Kelas IV SDN Mekarsari Dan SDN Cibiru 08 Kecamatan Cileunyi Kabupaten Bandung).

Palelupu Neo Davik. (2014). Pengembangan Media Pembelajaran Berbasis Adobe Flash Cs5 Pada Mata Diklat Gambar Teknik Di Kelas X TPM SMK Krian 1 Sidoarjo. Jurnal JPTM. Vol. 03 No. 02

Passerini, K. (2007). Performance and behavioral outcomes in technology-supported learning: the role of interactive multimedia. Journal of Educational Multimedia and Hypermedia; Norfolk Vol. 16, Iss. 2.

Philip. R. (1997). The developer's handbook to interactive multimedia: a practical guide for educational applications. London: Kogange.

Rahardjo, Turnomo et al. (2013). Literasi Media dan Kearifan Lokal "konsep dan aplikasi”. Mata Padi Pressindo

Rafiek. (2010). Teori sastra kajian teori dan praktik. Bandung: Refika Aditama

Rismawaty. (2017). Perkembangan Sejarah Sastra Indonesia. Banda Aceh. Bina Karya Akademika

Ruddell, M.R. (2005). Teaching content reading and writing. Amerika: Jhon Wiley \& Sons, Inc.

Samsuyurnita. (2012). Keterampilan Menulis. Medan: Universitas Muhammadiyah Sumatera Utara.

Sihabudin, Ahmad. (2013). Literasi Media Memberdayakan Kearifan Lokal. Jurnal Communication. Vol. 4No. 2

Siyamta. (2013). Pengembanagana Multimedia Pembelajaran Interaktif. Media Pembelajaran: Media \& Produksi. Malang

Sukardjo. (2006). Kumpulan materi evaluasi pembelajaran. Yogyakarta: Program Pascasarjana Universitas Yogyakarta.

Suyanto, M. (2005). Multimedia alat untuk meningkatkan keunggulan bersaing. Yogyakarta: Andi.

Sugiarto, E. (2015). Mengenal dastra lama: jenis, defenisi, ciri, sejarah, dan contoh. Yogyakarta: Andi Offset.

Stephen, B. Kucher. (2014). Dimensions of Literacy A Conceptual Base for Teaching Reading and Writing in School Settings. London. Routledge

Syahrani, Agus. (2013). Budaya Lisan Vs Budaya Literasi Mahasiswa Melayu: Implikasinya Pada Model Pembelajaran Mahasiswa.Wacana Etnik, (online), Jurnal Ilmu Sosial dan Humaniora. ISSN 2098-8746Vol 4, No 2.

Tarigan, H, G. (2013). Menulis sebagai Suatu Keterampilan Berbahasa. Bandung. Angkasa

Teoh, B.S.P., \& Neo, T.K. (2007).Interactive multimedia learning: students' attitudes and learning impact in an animation course. The Turkish Online Journal of Educational Technology. Volume 6 Issue 4 Article 3.

Tomlinson. (2014). Developing Materials for Language Teaching. USA: Bloomsbury Publishing Plc

Tompkins, G. E. (1997). Literacy for the 21st century: a balanced approach. Amerika: Pearson. Yunita, Reni. (2017). Pengembangan Multimedia Adobe Flash Cs5 Berbasis Stad Sebagai Media Pembelajaran Ipa Pada Pokok Bahasan Sistem Gerak Pada ManusiaUntuk Smp/Mts. Skripsi

Zhang, D. \& Zhou, L. (2003). Enhancing e-learning with interactive multimedia. Information Resources Management Journal, 16(4), 1-14. 